\title{
クリプトンレーザーを用いたラット血栓性 大脳皮質梗塞モデルに関する検討
}

定永 史子 ${ }^{1) *}$ 八尾 博史 ${ }^{1) 2}$ 井林 雪郎 ${ }^{1)}$ 藤島 正敏 ${ }^{11}$

要旨：ラットを用いて, 光感受性色素ローズベンガル $(20 \mathrm{mg} / \mathrm{kg})$ を静注し, 頭蓋骨上から クリプトンレーザー $(568 \mathrm{~nm} ， 4$ 分間) 照射することにより，血栓性大脳皮質梗塞モデルを作

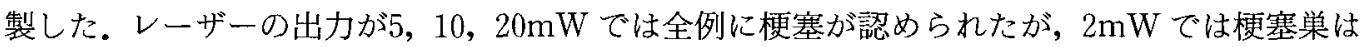
作製できなかった.色素レーザーを組み合わせたアルゴンレーザーに比較して,クリプトンレー ザーは調節設定が簡便である。しかもこのモデルは良好な再現性を示し，かつ脳表面温度の上 昇も少なく，均一な梗塞巣が形成され，脳血栓症モデルとしての条件を十分に満たしていた。 このモデルは，脳血栓症の病態解明や抗血栓薬の効果判定にも，有用なモデルとして今後活用 できるであろう.

Key words : photothrombosis, krypton laser, rose bengal, platelet aggregation, focal cerebral ischemia

(脳卒中20：267-271，1998）

\section{はじめに}

血栓症の発生要因はさまざまであるが，血管内皮の 傷害によってコラーゲンが露出したり，血管内皮の抗 血小板作用に機能障害が生じると, 血管内皮に血小板 が粘着し，血栓を形成することは周知の事実である。 しかし，これまでの脳梗塞モデルは，主に機械的に血 管を閉塞することにより作製されており，血小板と血 管内皮の反応は無視されてきた。1985年にWatson ら”咣感受性色素存在下に特定波長の光を照射する と, 光化学反応により産生された活性酸素, 主に singlet oxygen が血管内皮を障害し, 血小板主体の血栓が できることを見い出し, photothrombosis ${ }^{2}$ と称した. 今回この方法を利用して大脳皮質に限局した血栓性皮 質梗塞を作成し，同方法に対する改良点に関していく つかの新知見を得たので報告する。

\section{対象と方法}

（1）血栓性大脳皮質梗塞モデル

$9 \sim 12$ 週 齢の雄 Sprague-Dawley ラット（体 重

1) 九州大学医学部第二内科

2)国立肥前療養所

*現：脳血管研究所美原記念病院

（1997年12月25日受付，1998年2月19日受理）
330〜 420g）を用いた４％八ロセン（70\%笑気，30\% 酸素と混合)により麻酔を導入し, $1.5 \%$ ハロセン下に， 左大腿動静脈に PE50のカテーテルを挿入した.PE240 のポリエチレンチューブを用いて経口挿管後, パンク ロニウムブロマイド（初回 $0.3 \mathrm{mg}$ を静注，その後 30 分 毎に0.1mg 追加）により非動化し，人工呼吸器により 調節呼吸を行った。ラットは定位脳固定台に固定後, 手術操作中は八ロセン濃度は $0.75 \%$ とし, 維持量は $0.5 \%$ とた. 平均血圧, 直腸温, 頭部温度をモ二ター し, 動脈血ガス, 血糖值, ヘマトクリットを測定した。 光感受性色素ローズベンガル（和光純薬工業株式会 社，大阪） $(20 \mathrm{mg} / \mathrm{kg})$ を90秒で静注し，静注開始と同 時にクリプトンレーザー (Innova 302, Coherent Inc, CA, USA）(568nm)を頭蓋骨上から, bregmaより側 方 $2 \mathrm{~mm}$ 後方 $2 \mathrm{~mm}$ の部位に 4 分間照射した。

3 日後, アモバルビタール $(100 \mathrm{mg} / \mathrm{kg}$, 腹腔内投与 $)$ 麻酔下に右大腿動脈よりヘパリン $0.5 \mathrm{cc}$ 注入後, 墨汁 原液 $1 \mathrm{ml}$ を注入後, 断頭し脳を取り出した.取り出した 脳は 1 週間以上ホルマリンに浸けた後, 脳梗塞容積は $0.2 \mathrm{~mm}$ 間隔で冠状断へマトキシリン・エオジン染色を 施し, 脳梗塞面積を NIH Imageにより测定し, 面積 の加算から梗塞容樍を算出した。

（2）両側大脳皮質梗塞

行動薬理学的慢性実験に供するための両側前頭葉梗 
塞作製を試みた。 8 週齢の雄 Wistar ラット（体重 270 328g） 6 匹を用いて, 前述と同様の麻酔下に右大 腿静脈に PE50のカテーテルを挿入した。経口挿管後, パンクロニウムブロマイド ( $0.3 \mathrm{mg}$, 静注) により非動 化し, 人工呼吸器により調節呼吸を行った。ラットは 定位脳固定台に固定後，手術操作中は八ロセン濃度は $0.75 \%$ とし, 維持量は $0.5 \%$ とした。ローズベンガルは $20 \mathrm{mg} / \mathrm{kg}$ の半量を 45 秒で静注し, bregma より側方 3 $\mathrm{mm}$ 前方 $2 \mathrm{~mm}$ の部位にクリプトンレーザー $(10 \mathrm{~mW}$, 3 分）を照射し, 照射終了から 5 分後に再度ローズベ ンガルの残り半量投与と対側へのレーザー照射を行っ た。

数值は平均値士標準偏差で示した.

\section{結 果}

本実験中, 生理学的諸変量は正常範囲内にあった (表 1).レーザー照射直後に墨汁を注入し断頭したもので は, 図 1 に示しているように境界鮮明な血流途絶部が
認められ, 脳表の動脈は血栓により閉塞していること が観察できるが，照射野に含まれる静脈は開存してい た.クリプトンレーザーの出力を $5,10,20 \mathrm{~mW}$ にした 場合には全例で大脳皮質梗塞が認められたが， $2 \mathrm{~mW}$ では梗塞は作製できなかった(表 2 )。レーザー照射 3 日後のへマトキシリン・エオジン染色による冠状断切

表 1 生理学的諸変量

\begin{tabular}{ll|c|c}
\hline \multirow{2}{*}{} & \multicolumn{2}{|c}{ レーザー照射 } \\
\cline { 3 - 4 } & & 前 & 後 \\
\hline 平均血圧 & $\mathrm{mmHg}$ & $98 \pm 8$ & $103 \pm 5$ \\
脳温 & ${ }^{\circ} \mathrm{C}$ & $36.3 \pm 0.10$ & $36.5 \pm 0.03$ \\
直腸温 & ${ }^{\circ} \mathrm{C}$ & $37.0 \pm 0.2$ & $37.2 \pm 0.2$ \\
$\mathrm{PaCO}_{2}$ & $\mathrm{mmHg}$ & $33.2 \pm 1.7$ & $33.4 \pm 4.8$ \\
$\mathrm{PaO}_{2}$ & $\mathrm{mmHg}$ & $128 \pm 30$ & $117 \pm 34$ \\
$\mathrm{pH}$ & & $7.39 \pm 0.03$ & $7.39 \pm 0.02$ \\
ヘマトクリット & $\%$ & $39 \pm 2$ & $38 \pm 3$ \\
血糖 & $\mathrm{mg} / \mathrm{dl}$ & $137 \pm 15$ & $110 \pm 17$ \\
\hline
\end{tabular}

值は平均値 \pm S.D. $(n=16)$
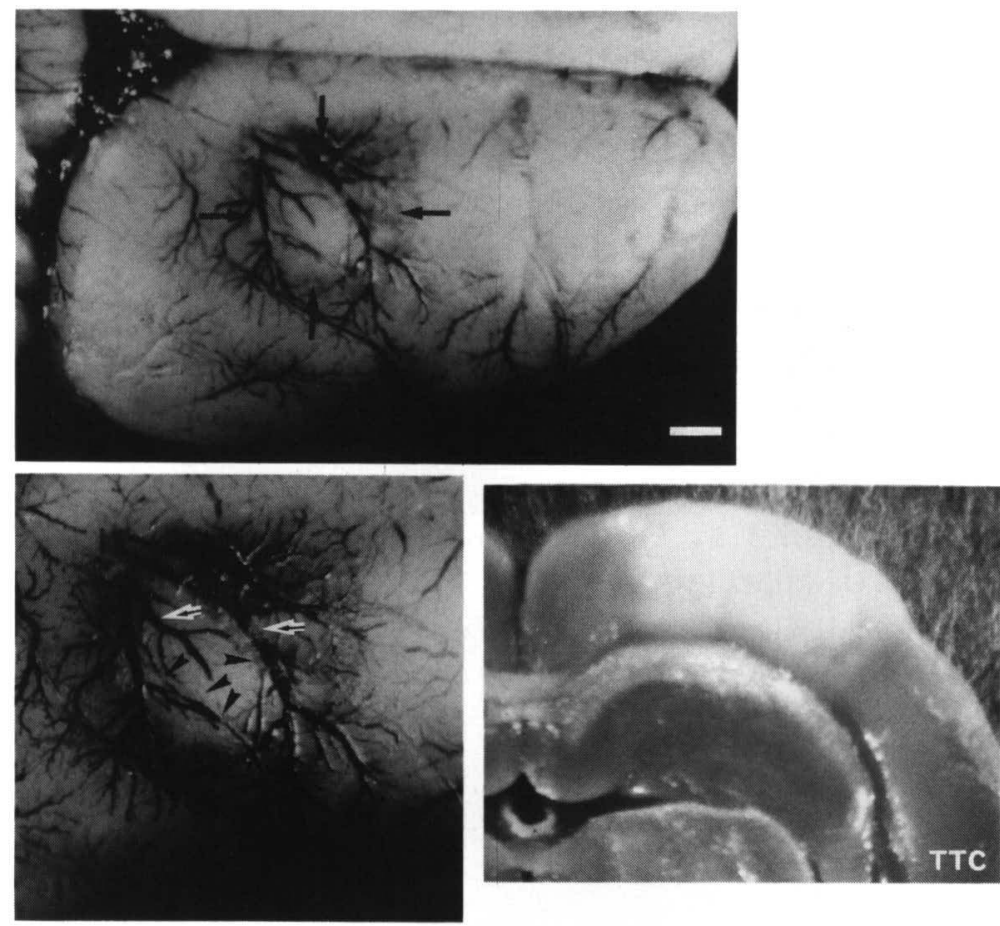

図 1 上段：レーザー照射直後に墨汁を動注し，断頭した脳標本. 肉眼的に血流欠損 部が認められる (矢印 $\rightarrow$ ) (白棒は $1 \mathrm{~mm}$ ). 下段左：上段の拡大所見. 照射野内の動 脈は閉塞し不明瞭となっている (矢頭〉) が, 静脈 (矢印引) は開存しており, 墨 汁の充満を認める.下段右：レーザー照射一日後に行った TTC 染色冠状断切片. 脳 梗塞になった部分が白い欠損部として認められる．脳梗塞は照射野に一致した大脳 皮質に限局している. 
片では, 半円状の皮質梗塞が確認され, $10 \mathrm{~mW}$ の出力 で作製した脳梗塞の容積は $14.2 \pm 4.3 \mathrm{~mm}^{3} \quad(\mathrm{n}=4)$ で あった。

レーザーは，ラットの頭蓋骨を約70\%通過する2)の で，骨上から照射した場合の $10,20,40 \mathrm{~mW}$ のリリプ トンレーザーに相当する $7,14,28 \mathrm{~mW}$ を頭蓋骨をはず した大脳皮質へ直接照射した場合の脳温の変化を検討 した. 図 2 に示すように, 通常の実験条件に相当する $7 \mathrm{~mW}$ の出力では脳温度は $2{ }^{\circ} \mathrm{C}$ 以内の上昇で, 許容範 井内であると考えられた。

両側照射においても, 図 3 に示すような両側性梗塞 が全例で一定の部位に作製できた，一匹に要する実験 時間は, 麻酔導入から抜管まで平均 $91( \pm 9)$ 分と比較 的短時間であった。なお，レーザー照射から断頭まで の 4 カ月の間, ラットの状態は良好であった.

表 2 レーザー出力と梗塞形成の割合との関係

\begin{tabular}{l|c|c|c|c}
\hline レーザー出力 & $2 \mathrm{~mW}$ & $5 \mathrm{~mW}$ & $10 \mathrm{~mW}$ & $20 \mathrm{~mW}$ \\
\hline 脳梗塞形成の割合 & $0 / 3$ & $6 / 6$ & $3 / 3$ & $4 / 4$ \\
\hline
\end{tabular}

考察

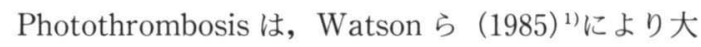

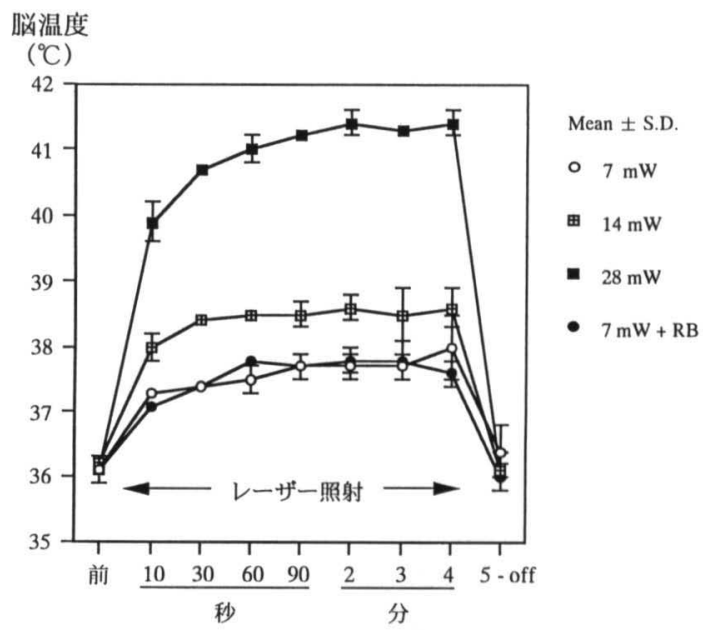

図2レーザー照射前後の脳温度の変化. 脳表を露出 後, 照射野皮質に温度プローペを刺入し, 各レーザー 出力での温度変化を経時的に測定した. RB：ローズ ベンガル
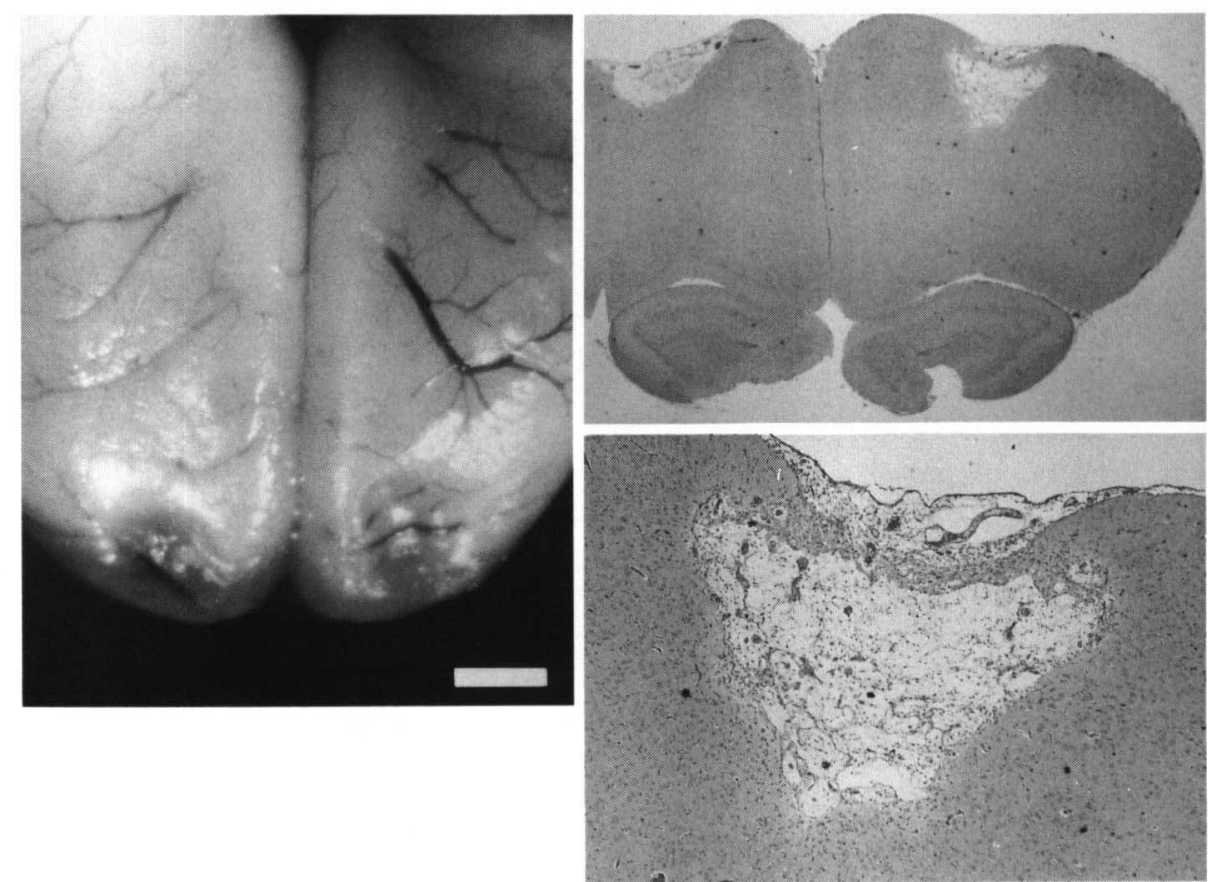

図3 左：両側前頭葉梗塞 (白棒は $2 \mathrm{~mm}$ ). 右上段：冠状断切片のへマトキシリン・エ オジン染色 $(4 \times)$. 右下段：上段の拡大所見 $(40 \times)$. 脳梗塞作成から 4 力月後の所 見であるので, 脳梗塞部は空洞に近い所見を呈している. 
脳皮質に限局した血栓性脳梗塞モデルとして発表され た.この方法の原理は, 酸素分子存在下で光感受性色 素と特定の波長の光との間での光化学反応を利用した ものである.光感受性色素ローズベンガル静注下に5 52 $\mathrm{nm}$ の波長の光を頭蓋骨上から照射すると, singlet oxygen を主とする活性酸素が血管内で産生され $ろ^{3 / 4)}$.これらの活性酸素は血管内皮の抗血小板作用を 障害し，同部に血小板が凝集し，血小板主体の血栓性 微小循環障害が生じ，その結果照射野にほぼ一致した 大脳皮質に限局した脳梗塞が作製できる ${ }^{122155}$.

Photothrombosis モデルの応用は，この大脳皮質血 栓モデルの他にも中大脳動脈閉塞モデル677), 脊髄梗塞 モデル ${ }^{81}$, 動脈原性塞栓モデル"9), 大脳皮質リング梗塞 モデル ${ }^{10)}$, 大脳皮質静脈閉塞モデル ${ }^{11}$, 虚血性大腸炎モ デル12)など多くのモデルが報告されている.しかしこ れまではアルゴンレーザーが使用されることが多かっ

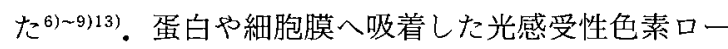
ズベンガルの最大吸光波長は $562 \mathrm{~nm}$ であり（生理学的 食塩水中では $548 \mathrm{~nm})^{2112)}$ ，この波長より離れるほど光 化学反応効率は不良となり, 同程度の反応を得ようと すれば出力を上げざるをえず，その結果熱を発生し， 脳温度が上昇する. $514.5 \mathrm{~nm}$ のアルゴンレーザー波長 は色素レーザーを用いて $562 \mathrm{~nm}$ へ変更できるので，最 大効率の光化学反応が期待できるが, 色素レーザーは 調節が繁雑である.Watson ら いるように，568nmのクリプトンレーザーを用いれば 十分な光化学反応がえられるはずであり, 実際に Yao ら ${ }^{14)}$ は中大脳動脈閉塞実験に㧍いてクリプトンレー ザーの有用性を示した．今回の実験でもレーザー照射 開始から 4 分以内に血管は閉塞したと考えられ，再現 性のある梗塞巣を形成し,かつ脳表面温度の上昇も $2^{\circ} \mathrm{C}$ 以内であった。

当モデルの特徵は次のように要約できる121.すなわ ち，血管内皮の機能障害により生体内に血栓ができる モデルであり，位置・大きさを自由に設定でき，頭蓋 外から照射可能なため開頭が不要であるという利点が ある.このように手技的にも簡便で侵襲が最小限であ るため, ラットの生存率は非常に良好であり，長期間 の慢性実験にも適している，通常の局所脳虚血モデル では侵襲性が高く作製困難な両側半球梗塞も容易に作 りえた。

一方, 終末動脈を閉塞してしまうため, 逆行性の側 副血行路からの血行を期待した治療には抵抗性があ $り$ ，血液脳関門の破綻による vasogenic edema の早期
出現9)などの病態は, 機械的中大脳動脈閉塞モデルに おいてみられる病態とは異なる点であろう。また, 本 モデルの血栓は血小板主体のものであり, フィブリン を多く含む静脈血栓とは組成が異なるため, tissue plasminogen activator などによる線溶療法の効果は 弱い15). しかし，このモデルは血管内皮の機能障害に よって生体内に血小板血栓を生じるモデルであるた め, 血小板血栓機序による微小循環障害の病態解明や 抗血小板薬 ${ }^{16)}$ の効果判定に扔いて有用性の高いモデル であろう。

以上クリプトンレーザーを用いることにより実験 系を可能な限り簡略化できた。また, 脳虚血の病態に 重大な影響を及ぼす脳温度に関しても検討し，我々の 実験条件が適切であることを確認しえた。

謝辞：病理標本を作製していただいた九州大学第二内科 病理研究室野口英子氏に深謝致します。な扔本研究の一部 は「平成 $8 \sim 9$ 年度厚生省循環器病研究委託 8 指 $-1 」$ にっ た.

\section{References}

1) Watson BD, Dietrich WD, Busto R, et al: Induction of reproducible brain infarction by photochemically initiated thrombosis. Ann Neurol 17: 497-504, 1985

2) Watson BD, Dietrich WD, Prado R, et al: Concepts and techniques of experimental stroke induced by cerebrovascular photothrombosis. In Ohnishi ST, Ohnishi T (eds): Central Nervous System Trauma: Laboratory Techniques and Recent Advancement, Boca Ranton, CRC Press, 1995, pp169-194

3) Gandin E, Lion Y, Van de Vorst A : Quantum yield of singlet oxygen production by xanthene derivatives. Photochem Photobiol 37 : 271-278, 1983

4) Lee PCC, Rodgers MAJ: Laser flash photokinetic studies of rose bengal sensitized photodynamic interactions of nucleotides and DNA. Photochem Photobiol 45: 79-86, 1987

5) Ginsberg MD, Busto $R$ : Rodent models of cerebral ischemia. Stroke 20: 1627-1642, 1989

6) Nakayama H, Dietrich WD, Watson BD, et al: Photothrombotic occlusion of rat middle cerebral artery: Histopathological and hemodynamic sequelae of acute recanalization. J Cereb Blood Flow Metab 8: 357-366, 1988

7) Markgraf $C G$, Kraydieh $S$, Prado $R$, et al: 
Comparative histopathologic consequences of photothrombotic occlusion of the distal middle cerebral artery in Sprague-Dawley and Wistar rats. Stroke 24 : 286-293, 1993

8) Prado $\mathrm{R}$, Dietrich WD, Watson $\mathrm{BD}$, et al: Photochemically induced graded spinal cord infarction. Behavioral, electrophysiological, and morphological correlates. J Neurosurg 67 : $745-753,1987$

9) Futrell N, Watson BD, Dietrich WD, et al: A new model of embolic stroke produced by photochemical injury to the carotid artery in the rat. Ann Neurol 23:251-257, 1988

10) Wester $P$, Watson $B D$, Prado $R$, et al: A photothrombotic 'ring' model of rat stroke-inevolution displaying putative penumbral inversion. Stroke 26: 444-450, 1995

11) Nakase H, Kakizaki T, Miyamoto $K$, et al : Use of local cerebral blood flow monitoring to predict brain damage after disturbance to the venous circulation: Cortical vein occlusion model by photochemical dye. Neurosurgery 37 : 280-286, 1995

12) Yano $Y$, Yao H, Aoyagi $K$, et al: Photo- chemically induced colonic ischaemic lesions: A new model of ischaemic colitis in rats. Gut 41: 354-357, 1997

13) Boquillon M, Boquillon JP, Bralet J : Photochemically induced, graded cerebral infarction in the mouse by laser irradiation. Evolution of brain edema. J Pharmacol Meth 27: 1-6, 1992

14) Yao $H$, Ibayashi $S$, Sugimori $H$, et al : Simplified model of krypton laser-induced thrombotic distal middle cerebral artery occlusion in spontaneously hypertensive rats. Stroke $27: 333-336,1996$

15) Watson BD, Prado R, Dietrich WD, et al: Mitigation of evolving cortical infarction in rats by recombinant tissue plasminogen activator following photochemically induced thrombosis. In Raichle ME, Powers WJ (eds) : Cerebrovascular Diseases, New York, Raven Press, 1987, pp317-330

16) Dietrich WD, Miller LP, Prado R, et al: Acadesine reduces indium-labeled platelet deposition after photothrombosis of the common carotid artery in rats. Stroke 26:111-116, 1995

\title{
Abstract \\ Photochemically induced cortical infarction in rats following kryplon-laser irradiation
}

\author{
Fumiko Sadanaga, M.D. ${ }^{1)}$, Hiroshi Yao, M.D. ${ }^{12)}$, Setsuro Ibayashi, M.D. ${ }^{1)}$ \\ and Masatoshi Fujishima, M.D. ${ }^{1)}$ \\ "Second Department of Internal Medicine, Kyushu University \\ ${ }^{2)}$ Hizen National Hospital
}

In a search for the simplest technical variations of photothrombosis we employed a krypton laser to induce photothrombotic cortical infarction in rats. The cortical region was irradiated by krypton laser transmission through the skull. The photosensitizing dye, rose bengal, at a body dose of $20 \mathrm{mg} / \mathrm{kg}$ was administered intravenously at a time interval of $90 \mathrm{sec}$. We confirmed reproducible infarction at laser powers of 5,10 and $20 \mathrm{~mW}$, but not at $2 \mathrm{~mW}$. The rise in brain cortical temperature during irradiation with the laser beam applied directly to the cortex at $7 \mathrm{~mW}$, which corresponds to $10 \mathrm{~mW}$ used through skull, was less than $2^{\circ} \mathrm{C}$; this was thus likely to avoid epiphenomena due to excess heat absorption. The advantages of our method may be summarized as follows. Highly reproducible infarcts can be produced, even though the model does not entail extensive surgery or opening of the skull. The 568-nm krypton laser does not require a high maintenance dye laser. Producing bilateral cortical intraction is also feasible. This thrombotic model affords useful standards for assessing the effects of antiplatelet treatment.

(Jpn J Stroke 20: 267-271, 1998) 